\title{
Transaction Costs on Online Transportation Partnership: An Empirical Study in Malang, Indonesia
}

\author{
Dodi Dermawan ${ }^{1 *}$ \\ ${ }^{1}$ Faculty of Economics Universitas Maritim Raja Ali Haji Tanjungpinang, Indonesia
}

\begin{abstract}
This study uses a digital platform with a partnership pattern between application companies and online transportation drivers. Previous studies reported that digital platforms were able to reduce transaction costs. This study aims to identify transaction costs in online transportation partnerships in Malang, Indonesia. Using a qualitative approach with interactive analysis, the informant is a two-wheeled online transportation driver in Malang City. This study revealed that several transaction costs in online transportation namely negotiated transaction costs when the driver is suspended and supervision transaction cost when the driver got problems with an error application server, lost internet network, parking fees for pick-up, and fake orders from customers. Further, transaction costs are also uncertain since the company's application regulations frequently change overtime. Despite the transaction fees, the drivers' overall income were much better compared to their previous job. To reduce these transaction costs, government regulations are needed to balance the rights of drivers. Moreover, the company could replace the suspension with a fine of a certain amount. Changes to rules and policies must accommodate input from driver partners since they are more aware of actual conditions Keyword
\end{abstract}

\section{Introduction}

The development of digital platforms in business is rapidly growing in order to meet the needs of customers with high mobility. Application companies in the online transportation business are companies that use digital platforms. They serve as intermediaries between drivers and consumers who want alternative transportation to avoid traffic jams, ease of use, fast, safe and low cost. The online transportation business model is part of the sharing economy which acts as an intermediary between stakeholders to conduct transactions [1]. This business model has changed ecosystems, markets, and work and consumption patterns [1-3]

The online transportation business model using a digital platform is different from the usual transportation business. The difference is that the company does not consider drivers as workers or employees but as partners of the company [4,5]. Many drivers join some application company partners to be online drivers because of flexibility of working time and increasing their welfare [6]. The current development of the sharing economy jeopardizes the nature of the sharing economy concept since many sharing economy actors such as online drivers are switching from part-time to full-time jobs [7].

The emergence of application companies in the sharing economy is generated by the efficiency and costeffectiveness. In order to reduce transaction cost, a sharing economy market is supported by Internet-based platforms. These platforms create new markets by offering convenience and much lower transaction fees between users and providers. Therefore, the transaction cost theory is the grounded theory for understanding the sharing economy concept [8].

A previous study found that the main variables of transaction cost in the online transportation business which are considered as the nature and characteristics of economic transactions are [9]: First, 'transaction frequency' refers to the number of transactions that occur during a certain period between the same parties or owning the same object (i.e the same shared assets on the sharing platform). Second, partner uncertainty relates to the transaction timeframe, which in turn affects the level of future contingencies that require contract adjustments, as well as contract risks that cause disputes in the governance of ex-post transactions.

Third, asset specification is the extent to which a specific and durable investment is required to maximize transaction value. An asset is specific when it has value in the context of a transaction but is relatively small in value outside of a transaction. Thus, the specificity of assets creates interdependence between the parties and creates a bilateral monopoly or unequal relationship in which the party who has made the investment can be exploited by another party who can deny or defend it. Based on the previous study, digital platforms should be able to reduce transaction costs, reduce information retrieval costs, and facilitate contracts. Considering these reasons in mind, this study aims to identify transaction costs on online transportation partnership in Malang, Indonesia.

\footnotetext{
*Corresponding author: dodydermawan@gmail.com
} 


\subsection{Sharing Economy in online transportation partnership}

The sharing economy has the characteristics of no ownership, temporary access, redistribution of material goods or assets of money, space, or time. Further, it also highly depends on advanced technology to provide accessible, flexible, and easy-to-share consumption [10]. The use of sharing economy is intended to overcome the problem of limited land while the population continues to grow and trigger people with have no place to store to share temporarily their goods [11]. The emergence of the sharing economy as a result of the global economic crisis that hit in recent years has provided opportunities for individuals to earn additional income and become an alternative job due to the difficulty of finding work, while the job-sharing economy offers flexibility in working [12]

The sharing economy is the value of taking underutilized assets and providing every other temporary online access to physical assets with the possibility to earn money and leading to a reduced need for ownership of those assets $[13,14]$. The sharing economy has three essential core characteristics namely economic access, economic platform, and communitybased economy. Economic access is a variety of ideas for sharing assets that are underutilized from one's resources or skills to be optimized and temporary, the economic platform is a set of initiatives decentralized exchange between individuals through digital platforms and a community-based economy refers to coordinating initiatives through non-contractual, non-hierarchical forms of interaction to do work or participate in projects or form exchange relationships [15]

Drivers or workers associated with platforms in online transportation such as Uber and Airbnb companies are not considered as workers or employees but as partners [4]. As a result, workers involved in these platforms are usually not regulated by labor laws and all workers' rights such as pensions, sick leave, salaries, holidays, occupational health and safety insurance that apply to most employees are skipped. Overall, a study reported that workers in the sharing economy growing rapidly though they get relatively low income [16]. However several problems arise where some platforms make it possible to use relatively unskilled labor. The impact is the low-skilled labor having greater potential to be exploited [17] and drivers having no bargaining power with the company [18].

Basically, the concept of a sharing economy is a mutually beneficial partnership for the parties concerned. A business partnership is an association consisting of two or more people, as co-owners who run a business for profit. Partnership is not only translated as a collaboration, but partnership has a pattern, has strategic value in realizing the success of an organizational institution [19].

\subsection{Transaction cost in sharing economy}

The main foundation in the assumption of transaction costs is partly on the concept of finite rationality, to understand transaction costs including the concepts of finite rationality, uncertainty, opportunism, asset specificity, and transaction frequency. All of these are factors that create transaction costs in the economy. There is uncertainty in the market and that all economic agents are rationally constrained and act opportunistically [20]

Opportunism is the basic foundation of transaction cost theory which is considered as a form of human nature [21]. Furthermore, opportunism is defined as "Self-interest alone with deceit", through distortion, hiding information, cunning actions and justifies all means [22]. In addition to being the foundation of transaction cost theory, opportunists also explain agency theory, that each party involved in the relationship will be motivated by economic self-interest and also opportunistic behavior [23]. Adam Smith once revealed that humans tend to behave according to their own interests [24]

Transaction costs are also known as exchange costs where the value of these fees depends on the specialization and frequency of transactions, negotiation skills, local knowledge, networks, confidence, social capital, and political connections. These transaction costs arise due to the high cost of information related to the exchange of property rights between individuals. This is due to the fact that humans are imperfect and have limited cognitive and calculative abilities [22]

The emergence of transaction costs is caused by human factors and environmental factors. The human factor is mainly due to inherent limitations as humans in the form of limited cognition and information (bounded rationality) and the desire to gain more profit in the wrong way (opportunistic) [24]. Further, environmental factors are the complexity of environmental conditions and various uncertainties that arise in society. Another expert articulated that transaction cost theory is part of organizational theory comprising activity costs such as production costs, opportunity costs, infrastructure costs (internal costs) and coordination costs (external costs) [25].

Transaction cost consists of search costs, bargaining, monitoring, enforcement, and indirect costs associated with the production of goods and services [26]. The essence of transaction cost economics is the costs that arise in relation to information, which consist of costs for carrying out measurements of the items exchanged and costs for protecting property rights and enforcing agreements. There are two types of transactions in society namely commodity transactions and institutional transactions [19].

In understanding the sharing economy, the theory of transaction costs is an underpinning theory [8]. Internetbased platforms facilitate extreme reductions in transaction costs between users and providers i.e. private accommodation and transportation. This creates an entirely new market which was previously limited. However, these new markets also replace existing accommodation and transport markets. Theories of substitution and complement must be added to transaction cost theory to analyze industry developments. As the cases of Airbnb and Uber have shown, not only substitution but also complementary. From the perspective of the reasons behind transaction costs and transaction processing, some major reason are 
uncertainty, limited rationality, and opportunism. Drivers and service users have limited knowledge of the services provided because their skills are lower than the standard level.

The relevance between transaction costs and working relationships in the sharing economy comprises [9] 'transaction frequency' refers to the number of transactions that occur during a certain period between the same parties or have the same object (i.e. the same shared assets in sharing platforms); 'partner uncertainty' relates to the time span of transactions, which ultimately affects the extent of future contingencies that require contracts, as well as contract risks that create problems in the governance of ex-post transactions; 'asset specification' is the degree to which a specific, durable investment is required to maximize transaction value. Assets are specific when they have value in the context of a transaction but relatively small value outside of a transaction. Thus, asset specificity creates interdependence between contracting parties and creates a bilateral monopoly or unequal relationship, i.e., the party that has made the investment can be exploited by another party who can deny or hold it [9]

\section{Methods}

The An interpretive qualitative approach is applied in this study. This method was chosen because of its suitability with the research objective to explore the phenomenon of transaction costs in online-based transportation. This study employed the cluster incidental sampling method at two application companies in Malang City with nine key informants [27]. The unit of analysis is about what and how transaction costs occur in partnership relationships on online transportation. Using an interactive model [28] to analyze the data, some activities are divided into several parts, namely data collection, data reduction, data presentation, and conclusions. The validity test was conducted with source triangulation and technique.

\section{Result}

\subsection{Informants at a Glance}

To find out the transaction costs in a partnership relationship on online-based transportation, it is necessary to record the informants detail in this study. Therefore, in this section, the profile of each informant is disclosed with pseudonym, it is displayed in Table 1.

Table 1. Key Informants Profile

\begin{tabular}{|c|c|c|c|c|c|}
\hline Name & Age & Education & & $\begin{array}{l}\text { Years } \\
\text { Joined }\end{array}$ & $\begin{array}{l}\text { Application } \\
\text { Company }\end{array}$ \\
\hline SW & 46 & $\begin{array}{l}\text { Senior } \\
\text { School }\end{array}$ & High- & 2 & Grab \\
\hline SL & 27 & $\begin{array}{l}\text { Senior } \\
\text { School }\end{array}$ & High- & 2 & Grab \\
\hline FE & 22 & $\begin{array}{l}\text { Junior } \\
\text { School }\end{array}$ & High- & 2 & Gojek \\
\hline RP & 24 & $\begin{array}{l}\text { Senior } \\
\text { School }\end{array}$ & High- & 2 & Gojek \\
\hline YS & 32 & $\begin{array}{l}\text { Undergradua } \\
\text { School }\end{array}$ & late & 2 & Gojek \\
\hline BY & 40 & $\begin{array}{l}\text { Senior } \\
\text { School }\end{array}$ & High- & 4 & Grab \\
\hline
\end{tabular}

\begin{tabular}{|c|c|c|c|c|}
\hline YR & 35 & $\begin{array}{l}\text { Elementary } \\
\text { School }\end{array}$ & 1 & Gojek \\
\hline $\mathrm{TP}$ & 38 & $\begin{array}{l}\text { Undergraduate } \\
\text { School }\end{array}$ & 2 & Grab \\
\hline FR & 51 & $\begin{array}{l}\text { Senior } \\
\text { School }\end{array}$ & 2 & Grab \\
\hline
\end{tabular}

There are 9 key informants used in the study, five informants join the Grab application company and four informants join the Gojek application company.

\subsection{Transaction cost in online transportation partnerships}

Transaction costs in this study are costs incurred by driver-partners when they firstly join and start working, ranging from information seeking, negotiation costs, supervision, and uncertainty. In this study, the cost of information is the fee for obtaining information such as the cost of data packages or the cost of credit. Negotiation Fees are costs incurred by the driver when he firstly joined such as administrative costs i.e the ID card, SKCK, driver's license, bank account, and vehicle registration with a motorbike for at least five years back. The next requirements are to have a Smartphone with at least $3 \mathrm{~GB}$ of RA and to buy riding equipment consisting of helmets and jackets from the company.

The process when a driver wants to join an app company is evolving. At the beginning of the company's operation, the application required that prospective drivers who wanted to join the company had to come to the office, prepare hardcopy files and sign an agreement. But for the last few years, prospective drivers who want to join the company are not required to come to the office, the required files are downloadable in the application and the agreement with the company is only through the application form. Mr. SW, when he first joined in the last 1 year he said the following: "I got the information that when I first joined the company, it wasn't that difficult because my friends had already joined. I ask a lot of friends and look for information on the internet. The cost is only to take care of administrative completeness such as SKCK and SIM if you don't have one. It cost me a lot to buy a cellphone with a minimum of $3 \mathrm{~GB}$ of RAM, while for the cost of a helmet and jacket yesterday I was deducted from my Go-pay balance every day".

From Mr. SW's statement, it indicates that the cost of finding initial information to join the company is little bit small, because the information is easily and economically obtained. However, the company stipulates requirements for the equipment needed by the drivers to support their work such as cell phones and motorbikes. All these are charged to the drivers before joining the company. Therefore, it is common for drivers to apply for loans for vehicles and smartphones which are paid monthly from driving income. Meanwhile, the major costs incurred by drivers in carrying out their daily work activities are operational costs such as vehicles and consumption.

Mr. SL: "The costs are quite large, especially for vehicles ranging from fuel to maintenance, consumption, and cigarettes". 
Mr. FE: " "The big cost is the vehicle because if the vehicle is damaged the costs are quite large, the company is not there to help the driver to reduce vehicle maintenance costs, and the cell phone if the cell phone is damaged even though there is insurance, the claim is very difficult and complicated".

From the statement of Mr. SL and Pak FE, it suggests that the operational costs are quite large, both for the vehicle and for the consumption of the driver. The cost is already affordable by the company so there are several solutions that the company offers such as collaborating with self-help partners who offer vehicle services or food stalls at special prices that are cheaper for drivers who are company partners. However, some drivers also complain that the number of independent partners is limited and very few. It sometimes makes long queues and takes a long time to access while in the same time drivers are being chased by target orders to get bonuses every day. Therefore, this solution is quite ineffective.

Regarding insurance products, the company has collaborated with insurance companies for driver and passenger accidents. Every online motorcycle taxi driver gets an insurance policy as recommended by the government from the application company. Accident insurance will cover everything from medical treatment and permanent disability to death. The accident insurance premium is borne by the application company and the driver do not need to pay the premium. As for other insurance products, it is up to the driver's own choice. Smartphone insurance products protect smartphone screen damage with a payment of 20 thousand rupiahs per year. Moreover, there is also loss insurance for motor vehicle damage with a payment of 50 thousand per year with an insured value of up to 2.5 million rupiahs. However, claiming damage to the smartphone screen is a bit complicated, this is what some drivers complain about.

The transaction cost in the negotiation occurs when the driver is suspended from the company. Driver's account is suspended because they made a mistake and got punished by the company. Transaction cost may increase if they need to rent the account of the driver who is not working.

Mr. RP explained as follows: "If we get a temporary suspension, we usually go to the office to ask for an explanation, our costs increase because of the cost of gasoline and other costs. While we have no income because we don't work, other expenses cannot be stopped such as food, cigarettes, and so on. Usually, in the office, the explanation from the company is also not satisfactory and rarely works.".

Mr. YS: "I usually just give up if I get suspended temporarily, just to get income when I get sanctioned, I usually use a friend's account who doesn't work that day, and this rental fee is a burden that shouldn't be borne".

From the explanations of Mr. RP and Mr. YS, it reveals that the suspended driver's account is very burdensome for the driver. Drivers who make this online transportation job as their main job experience a loss of daily income. Overhead costs such as food and drink costs, credit installment costs, vehicle operating costs cannot be stopped temporarily. This, of course, will drain their savings or force them to borrow money from other parties. Drivers will rent the account of the driver who is not working with the consequence that they need additional costs for rental fees and this is also illegal.

Supervision or monitoring costs are costs incurred when drivers experience problems both in the field and in the application system, for example when drivers experience problems with application server error, lost internet network, parking fees for pickup, and fake order fees from customers. Transaction costs in transaction uncertainty are when company rules change frequently. Further, operating costs may also increase transaction cost because drivers have to work for longer hours to gain bonus points. The system to get orders applied to the driver is always changing, the system changes from this company without any coordination with driverpartners. This causes transaction uncertainty for drivers, resulting in higher operational costs.

Mr. BY explained as follows: "In the past, gasoline was more efficient, if we got an order after we finished, we got another order to our place again, if now we get an order and keep going back to where we were waiting for an hour to get it again, so gasoline is wasteful".

Mr. YR: "The current revenue-sharing system reduces our revenue. We work from six in the morning, usually every day we try to close points, it turns out that this distribution is very detrimental to drivers who are usually routine, while those who don't work regularly get the same, now with a system like this it is difficult to close points, on average they only get 10 order a day. Mr. TP: "This application system change sometimes makes our account slow to get orders. Before there was a change in the account application system, I often got orders without having to change places. Many of my friends have taken part in the application system modification service so that their accounts can get more orders and spend a lot of money, some are successful and some are not".

From the statements of Mr. BY and Mr. YR there are some problems regarding the change of the order system in which it made them uncomfortable. Before the change, the drivers already felt in their comfort zone with the income and expense routines that the driver could predict. As the time passed, the company made changes to the equalization order system where one driver gets one order for one hour. This change has not accommodated drivers' opinions and voices. When this system is implemented, drivers who are more diligent in getting orders get the same amount of orders as drivers who are not diligent.

This order distribution system has an impact on those who depend on full-time jobs as online motorcycle drivers. Those who make this as part-time job and have a little time will also get the same benefits as full-time ones. The impact is lowering the income for full-time drivers because the bonus is not fully achieved. In 
addition, operational costs increase because the mobilization of vehicles is high and the working time is also getting longer.

Changes to the application system also impacted the driver's account becoming slower in getting orders, as stated by Mr. TP. This has led to the emergence of technology services that can modify the driver's account. They offer their services on social media like Facebook or Instagram and from whatsapp groups. The driver spends a number of fees to pay for the service of modifying his account application so that it is easy to get an order. This service is illegal and if it is known by the company, it will be penalized for termination of the partner. Though not all of these account modifications are successful, more and more drivers are being deceived by people who can modify driver accounts to improve account performance and get more orders.

Although the transaction costs incurred by the drivers are quite large, they agree that these costs can still be covered by the income from orders so far. The amount of this fee is also directly proportional to the income received by the driver. This is the reason for them to continue as online transportation drivers by bringing home a better income than their previous job.

Mr. TP described the following: "The income received as an online motorcycle taxi is quite good, only the policy that is always changing makes the income fluctuate".

Mr. FR explained as follows: "I used to work in a supermarket, the income I received was only the UMR with incentives, now I take an online motorcycle taxi, the income I receive is more than the UMR and Incentives, only the working time becomes uncertain.

Mr. YR:"Before joining online motorcycle taxis I worked in a repair shop, my income was not as big as it is now, welfare has indeed increased since joining online motorcycle taxis"

From the respondent's statements, it figures out that the income of the drivers as a whole has increased from their previous job. Earnings increase along with the longer hours of the previous job. The longer the working time, the more their income will increase and the costs will also increase. The company is able to improve the welfare of drivers though there are problems in terms of transaction costs which have also increased respectively. This transaction is inseparable from the uncertainty of costs caused by the rules and policies of the company itself which is always changing and inconsistent can lead to uncertainty that leads to the emergence of transaction costs.

\section{Discussion}

The use of platform applications has created a variety of new businesses which can reduce transaction costs [8]. The findings in this study reveal that transaction costs arise not on the application technology platform but rather on the rules and policies of the application company. The use of platform application technology in the online transportation business has increased the welfare of online motorcycle drivers since their income is better than their previous job. Digital platforms have created efficiencies in information costs and make it easier for consumers and producers. All parties involved in transactions through the platform will be more efficient than transacting directly [29].

Transaction costs in online transportation are caused by the uncertainty factor experienced by driverpartners regarding company policies, rules, and sanctions. The company sanctioned the temporary suspension of operations for the driver which was very burdensome for the driver and in fact resulted in a large cost. For this reason, the company can replace the driver's temporary suspension with a fine imposed on the driver. Fines are considered sufficient and provide a deterrent effect for drivers who violate. Furthermore, the company's ever-changing policies can lead to large transaction costs. Changes in rules and policies must also involve input from driver-partners because drivers are more aware of actual conditions [30]. The consistency of established policies must be transparent and static. Policies that are always changing in the short term will directly harm drivers and in turn, will harm the company indirectly.

The online transportation partnerships that have been built are still dominated by application companies, and driver-partners are only passive partners who have little effect on the partnership. In several studies, it was found that the company's platform not only acts as an intermediary but also determines the price of services unilaterally and controls various rules [30]. The company has strong information control so that drivers do not have the power to negotiate what their rights are [18]. For this reason, the government's role is needed in balancing their rights such as making regulations and facilitating driver-partners to form independent and legal driver-partner associations [31].

\section{Conclusion}

Transaction costs in online transportation are divided into four, namely information search costs, bargaining costs, monitoring costs and transaction uncertainty. The cost of searching for information is very economic because the information obtained by the driver is easy to access through the company's website and application. The transaction fee in the negotiation is when the driver is suspended, to earn income they will rent out the account of the driver who is not working. Transaction fees under surveillance are when drivers experience problems with application server errors, loss of internet network, parking fees for pickup, and fake orders from customers.

Transaction costs in transaction uncertainty are when company rules change frequently. Transaction fees increase as drivers have to work longer hours to cover bonus points so operating costs will increase as well. Although there is a transaction cost in the online transportation partnership, the driver's overall income has increased from their previous job. This research only identifies some transaction costs. Further research is needed to explain the transaction cost factors in detail in online transportation partnerships sphere. It is expected 
that this research could be a reference to get the variables used in transaction costs in online transportation partnerships.

\section{References}

1. F. Caldieraro, J. Z. Zhang, Jr. Marcus Cunha, and J. D. Shulman, Journal of Marketing 82, 42 (2018).

2. C. P. Lamberton and R. L. Rose, Journal of Marketing 76, 109 (2012).

3. G. Zervas, D. Proserpio, and J. W. Byers, Journal of Marketing Research 54, 687 (2017).

4. C. F. Wright, N. Wailes, G. J. Bamber, and R. D. Lansbury, Employee Responsibilities and Rights Journal 29, 247 (2017).

5. J. V. Hall and A. B. Krueger, Ilr Review 71, 705 (2017).

6. A. Mas and A. Pallais, American Economic Review 107, 3722 (2017).

7. C. Liu, R. K. H. Chan, M. Wang, and Z. Yang, Sustainability (Switzerland) 12, 6333 (2020).

8. A. H. Henten and I. M. Windekilde, INFO 18, 1 (2016).

9. Y. H. Akbar and A. Tracogna, International Journal of Hospitality Management 71, 91 (2018).

10. R. Bostman and R. Rogers, What's Mine Is Yours: The Rise of Collaborative Consumption (Editorial Collins, 2010).

11. F. Bardhi and G. M. Eckhardt, Journal of Consumer Research 39, 881 (2012).

12. K. Dervojeda, The Sharing Economy: Accesbility Based Business Models (European Commission, 2013).

13. A. Stephany, The Business of Sharing: Making It in the New Sharing Economy (Palgrave Macmillan, 2015).

14. K. Frenken and J. Schor, Putting the Sharing Economy into Perspective (Edward Elgar Publishing, 2017).

15. A. Acquier, T. Daudigeos, and J. Pinkse, Technological Forecasting and Social Change 125, 1 (2017).

16. J. Bughin, J. Manyika, S. Lund, K. Robinson, J. Mischke, and D. Mahajan, McKinsey Global Institute 1 (2016).

17. A. D. Nastiti, Worker Unrest and Contentious Labor Practice of Ride-Hailing Services in Indonesia (Evanston, IL: Northwestern University, 2017).

18. A. Rosenblat and L. Stark, International Journal of Communication 10, 3758 (2016).

19. E. F. Schumacher, Economics as If People Mattered, Thesis, 1977.

20. O. E. Williamson, De Economist 146, 23 (1998).

21. C. C. Chen, M. W. Peng, and P. A. Saparito, Journal of Management 28, 567 (2016).

22. K. Grønhaug and M. C. Gilly, Journal of Economic Psychology 12, 165 (1991).

23. X. Luo and N. Donthu, Journal of Business \&amp; Industrial Marketing 22, 452 (2007).

24. A. Benham and L. Benham, The Elgar Companion to Transaction Cost Economics 107 (2010).
25. K. Kant, M. Hussain, and S. Suhrawardy, Sunrise Publishers \& Distributors (2007).

26. B. W. Husted and R. Folger, Organization Science 15, 719 (2004).

27. J. Creswell and C. Plano, Designing and Conducting Mixed Methods Reseach (Sage publications, 2017).

28. A. M. Miles, M.B \& Huberman, Sage Publications 1 (1994).

29. T. R. Eisenmann, Strategic Management Journal 27, 1183 (2006).

30. D. Dermawan, K. Ashar, I. Noor, and A. Manzilati, The Journal of Asian Finance, Economics and Business 8, 1101 (2021).

31. D. Dermawan, K. Ashar, I. Noor, and A. Manzilati, 144, 29 (2020). 